\title{
LEADERSHIP DEVELOPMENT IN LEADING COUNTRIES OF WESTERN AND NORTHERN EUROPE
}

\author{
Roman Storozhev \\ Ph.D., Assistant Professor, National Academy of Public Administration \\ under the President of Ukraine, Ukraine \\ e-mail: ris03021976@ukr.net,orcid.org/0000-0001-5103-7274
}

\section{Summary}

At the current stage of Ukrainian state integration into European community, country leaders face new challenges that require efficiency improvement of public management and public administration based on democracy and human-centeredness.

Urgency of public leadership development in Ukraine is closely related to the foreign countries' experience study on the mechanisms of formation and development of public leadership, characterized by a high level of moral values, responsibility, communication, modesty. The new management paradigm, being implemented in public administration and public management in Ukraine, also requires introduction of new qualities in public leadership, manifested through establishment of moral values in the leader's personality, leader's behavior in public service reform. According to the author, such qualities of leadership as delegation of powers in public authorities, intersectoral cooperation in public administration determine development of leadership in the context of educational trends in foreign countries.

The author believes that today an important aspect in the development of public leadership is the mobilization aspect of the efforts of all leaders and subordinates of public authorities and leaders of civil society institutions to overcome crises and do complex reforms in public administration. Such crises include ensuring stability in global fight against the GOVID-19 pandemic. However, problem of public leadership development in this aspect has not been properly reflected in modern scientific sources.

The article reveals priority models of public leadership of Western Scandinavian countries as a prerequisite for formation of successful personality, successful leadership qualities, the trend of which is such an important factor as publicity, because before the 90s of the twentieth century not all government officials in European countries were public.

Keywords: leadership qualities, personality of the leader, typology of leadership, moral values, responsibility, communication, modesty, publicity, civil society institutions.

DOI: https://doi.org/10.23856/4529

\section{Introduction}

The focus on leadership transparency in Western European countries has been part of the major shift in the role of top officials, as it was expected of them to demonstrate public leadership (Chappelet, 2017). This was one of the important trends in the development of leadership as not all officials until the 90 s were clearly public.

In this article the author will consider the features of the public leadership development in the Scandinavian countries such as Norway, Sweden, Denmark, part of leading countries of Western Europe - the Kingdom of the Netherlands and Switzerland. After all, the new management paradigm, which is actively implemented in the domestic public administration, requires 
the formation of new qualities in public leadership, which are manifested through the assertion of moral values of the individual, his behavior in communication, self-management and stressful situations. Such leadership qualities as the ability to self-education, delegation of the authority, transparent (transparency, openness and activation) and transformational cooperation determine a new style of leadership development in Western European countries, which will be useful for implementation in Ukraine (Kalashnik, 2013).

The analysis of recent researches shows that the problem of modern leadership in public administration is constantly viewed by domestic and foreign scholars. V. Golub, N. Honcharuk, V. Goshovska, I. Hryshchenko, G. Dmytrenko, L. Karamushka, O. Kryukov, B. Kukhta, N. Nyzhnyk, T. Novachenko, M. Piren, F. Rudych, I. Surai, L. Pashko and others made such a significant contribution to the study of leadership in public administration with the specification of its principles. However, the research question of major principles of leadership in public administration in public administration science in the context of public service reform has not received proper scientific justification, which determines the relevance of the research topic.

\section{The main features of public leadership in public administration development in the Kingdom of the Netherlands}

Today the issues of leadership, its major principles and the development of leadership potential are on focus of scholars and practitioners who are aware of their importance for effective public administration reform and democracy development.

The Scandinavian countries should be considered as an example of how in fairly harsh climatic conditions it is possible to build a model of socio-political system with highly developed economy, a high standard of living, respect for people's rights and freedoms.

The Kingdom of the Netherlands determines that one of the important human factors of a person involved in public administration and adapted to new challenges is his "quality". Therefore, public officials in this country are required for continuing education, particularly in the field of e-democracy (Faculté de droit, des sciences criminelles et d'administration publique, 2020).

There is no doubt that information and communication technologies, opening new opportunities not only for modernization but also for greater transparency in the activities of government authorities and top managers, contribute to increasing the democratic participation of citizens in political life of the state and leadership development.

In this context, much attention is paid to continuing education, which distinguishes between career-oriented long-term programs and short-term training for a specific tasks or job. In such matters there is a connection and interaction between the government, public and private universities (Faculté de droit, des sciences criminelles et d'administration publique, 2020).

Another feature of the political and administrative system of the Netherlands that should be highlighted and which influences the development of leadership is the interaction between politicians and officials. Yes, politicians with administrative experience, after completing their political careers, mostly hold administrative positions at various levels. Such experience gives officials the opportunity for mutual understanding that contributes to effective interaction and the formation of leadership teams in public administration. It is obvious that the principle of publicity reveals the personality of the leader, accompanied by the acquisition / changing of ideas about his professionalism, values, self-fulfillment as a manager, etc., which may define / not define the leader as a person to be followed. 


\section{Leadership development in public administration of Scandinavian countries}

The main providers of public services in Sweden are local municipalities, whose work is based on the following principles: democracy - all public power is exercised through the people by universal suffrage, representative democracy and a parliamentary system; obedience to the law - public authorities must strictly comply with the law; objectivity - impartiality and equal treatment of all people; freedoms - free formation of opinions and freedom of expression; respect - public authority must be exercised through respect for the freedom and equality of every human being; efficiency and service - public sector activities should be carried out inexpensively and with the highest possible quality, taking into account available resources (Page E., Wright V., 2007: 135).

According to the current constitutional legislation of Sweden, the right to establish a system of public administration, the status of the civil service, the conditions of its passage is given to the Riksdag. The administrative apparatus of the center and local level is managed by the government (Page E., Wright V., 2007: 145-185).

The first group includes "political officials", including ministers, their deputies, heads of government departments, prosecutors, governors, police chiefs and so on. Specifically, the main composition of senior and middle administrative staff does not depend on the political orientation of the government, and therefore is unchanged. For such employees, promotion is permissible, but transfer against their will or dismissal before reaching the established age is not allowed. Municipalities are independent of the central government and independent in determining financial status and staffing. Their employees do not belong to civil servants, while such a concept as "rank of civil servants" does not exist (Ibid).

Civil servants are required to have high professionalism and relevant personal qualities. The training of civil servants in Sweden is carried out in universities, their education has traditionally been economic or legal, which corresponds to the essence of the Anglo-Saxon approach to their education. However, receiving professional education, civil servants have a strong training in the field of law, but improving the quality of work is associated with the application of an interdisciplinary approach, which expands their opportunities for successful management (Ibid).

The use of training programs in the context of an interdisciplinary approach, allows you to develop and improve systematic and critical thinking, communication skills, self-organization, creativity, teamwork skills, etc., undoubtedly contributes to leadership development.

Turning to the analysis of professional development of the officials in Norway, we see that their retraining is absent. They adhere to the imperative that passing the competition to occupy the vacant post of public service gives every specialist a reason to fully perform their professional duties. At the same time, the system of advanced training of public servants is based mainly on self-education. This applies to the process of self-acquisition of knowledge and skills both individually and during the course (Meer F.M. van de, Kerkhoff A.D.N., Osch D.A.G.T. van., 2014: 20-23).

Public servant of Norway can apply to an educational institution and study on his / her own. Such services are most often provided by Higher Public Schools, which conduct free courses on democracy development, involvement of citizens in the development of society, creation of conditions for self-development, self-realization, training of leaders, etc.

The defining form of professional development is self-education, which develops leadership by providing important competencies. In the performance of functional duties, the quality of their implementation directly depends on the ability of the employee to self-education, 
which is considered as the standard of public service (Meer F.M. van de, Kerkhoff A.D.N., Osch D.A.G.T. van., 2014: 23).

\section{The continuing education for leadership in public administration of Switzerland}

Switzerland is a federal parliamentary republic, its public administration is governed by the provisions of the Constitution (1999), the basic principles of which are respect for federalism and democracy (Guide to modern and effective human resource management. 2013: 20-23).

Significant achievement of Swiss democracy is the various tools of direct democracy, which allows citizens to be active participants in elections, referendums, legislative initiatives, public meetings of voters etc. (Ibid).

Civil servants and their leaders need to introduce new ways and methods of leadership that allow them to perform their tasks more fully. This means the need for continuing education, which can be carried out in leading higher education institutions. One of them is the Institute for Advanced Studies in Public Administration (Swiss graduate school of Public Administration french: Institut des hautes études en administration publique, IDHEAP). It is one of the most popular in the system of professional training of civil servants and their leaders (Ibid).

This education institution trains government officials, their leaders and those who plan to work in public area after graduation. IDHEAP training programs are approved at the confederation level, and the Master's degree in Public Administration has been accredited by the European Association for Public Administration Accreditation. The training of students in IDHEAP is carried out within the framework of the main programs: master's degree in public administration, as well as public management and policy, doctoral studies in public administration (Ibid).

Along with teaching IDHEAP conducts the researches and consulting on issues of public administration, professional training for members of administrative bodies, aimed at leadership development.

Another feature of Swiss system of public administration is the great attention to the recruitment of future civil servants. Selection of candidates in the public administration system takes place under the conditions of open competition and interviews with potential direct supervisors. For searching of candidates it is used well-known social networks, such as: Facebook, Linkedin, as well as specialized portals, in particular: Federal jobs portal: www.stelle.admin.ch/ stelle/fr/home.html, specializing in the recruitment of civil servants (Ibid). Among other important requirements for such recruiters we should mention the availability of professional education that corresponds to the exact position; higher education corresponding to the level of bachelor, master or PhD.

The necessary requirements also include knowledge of national languages, each employee of the municipality must speak at least two languages $(71 \%$ German, $22 \%$ French, $7 \%$ Italian). Personal qualities and the ability and desire to continuing education and self-improvement are also taken into account (Van der Hoven R., 2020).

\section{Conclusions}

Thus, the analysis of foreign experience in leadership development in the context of educational trends in the Scandinavian countries - Sweden, Norway, the Netherlands and Switzerland shows that European integration has led to interactions in this process.

It is determined that the defining feature in the political and administrative system of the Netherlands is the interaction between politicians and officials, that influences the development 
of leadership. Yes, politicians having an administrative experience, after completing their political careers, mostly hold administrative positions at various levels.

Sweden is one of the most innovative and cooperative countries in the world, presenting itself as a global changing leader in promotion and supporting the concept of sustainable development. The success of this concept requires a coordinated effort of the entire system of public administration, according to which the country's development policy is based on a unique mix of innovation and cooperation. The so-called "policy labs" help government agencies to meet the needs of society, successfully make regulatory changes and facilitate innovations that will stimulate social sustainable development.

So in order to make a career and hold a senior position in Norway, to become a leader and improve your financial well-being you need to study continuously.

Swiss public administration is based on such fundamental principles as neutrality and direct democracy. Practice has shown that the transfer of powers from the center to the cantons and communities increases the efficiency of public administration in the country.

The outlined unanimity revolves around the understanding and awareness of civil servants and managers-leaders of the importance of lifelong learning, the importance of recruitment and non-admission to this category of random and unprofessional people. This makes it possible to affirm the importance of updating the experience, educational trends of European countries and their creative adaptation in Ukraine.

\section{References}

An Introduction to Shared Values for Civil Servants / Swedish Council for Strategic Human Resources Development. URL: https://www.his.se/PageFiles/3429/Shared\%20Values\%20 for\%20Civil\%20Servants.pdf [in Swedish].

Chappelet J.-L. Trends in Swiss Civil Servants Training. CSPTC 2017. URL: http://www.csptc. gov.tw/_hrd/2017/images/speech3.pptx. [in English].

Działania Urzędu Stużby Cywilnej mające na celu poprawę funkcjonowania administracji publicznej. URL: https://www.nik.gov.pl/plik/id,1556.pdf; [in Polish].

Faculté de droit, des sciences criminelles et d'administration publique URL: http://www. idheap.ch/idheap.nsf/vwbasedocuments/idmpa01 [in French].

Gierelo K. (2003) Wizerunek (image) - teoria i praktyka. Wrocław: Wyd. Uniwersytetu Wrocławskiego. 345 s. [in Polish]

Kalashnyk N. S. (2013) Samoosvita dezhavnykh sluzhbovtsiv : kompetentnisnyy pidkhid : monohrafiya [Self-education of state employees: competence approach: monograph]. Dnipro, P. 149 [in Ukrainian].

Kempa B. : Celem KSAP jest kształcenie przyszłych liderów. URL: http://www.radiomaryja.pl/ informacje/b-kempa-celem-ksap-ksztalcenie-przyszlych-liderow [in Polish].

Meer, F.M. van de, Kerkhoff, A.D.N., Osch, D.A.G.T. van. (2014). Educating and training civil servants in the Netherlands 1814-2014. IIAS Administrative History Conference, Corfu, April 26, 2014. Corfu, Greece: IIAS Administrative History study group, pp. 20-25. [in English]. Nowoczesne przywództwo $w$ organizacji publicznej na rzecz zmian - rola wyższych stanowisk w stużbie cywilnej. URL: https:// www.dsc.kprm.gov.pl/sites/default/files/skrypt-_gamma.pdf [in Polish].

Oferta szkoleń 2018. URL: http://ksap.gov.pl/ksap/sites/default/files/files/oferta_szkolen_2018_0.pdf [in Polish]. 
Plan szkoleń centralnych $w$ stużbie cywilnej na 2011 r. URL: https://dsc.kprm.gov.pl/sites/ default/files/plan_szkolen_centralnych_w_sluzbie_cywilnej_na_2011_r.pdf [in Polish].

Plan szkoleń centralnych $w$ stużbie cywilnej na 2018 r. URL. $:$ https://dsc.kprm.gov.pl/sites/ default/files/plan_szkolen_centralnych_w_sluzbie_centralnych_na_2018_rok.pdf; [in Polish].

Polityka szkoleniowa w stużbie cywilnej. URL: https://dsc.kprm.gov.pl/sites/default/files/pliki/ zal._nr_2.pdf [in Polish].

Poradnyk iz suchasnoho ta efektyvnoho upravlinnya lyuds'kymy resursamy. Rada Yevropy [Guide to modern and effective human resource management]. Council of Europe: 2013. P. 26 [in Swedish].

Rozporządzenie Prezesa Rady Ministrów z dnia 24 czerwca 2015 r. w sprawie szczegółowych warunków organizowania i prowadzenia szkoleń w stużbie cywilnej. URL: http://prawo.sejm. gov.pl/isap.nsf/download.xsp.pdf [in Polish].

Rozporządzenie Prezesa Rady Ministrów z dnia 24 czerwca 2015 r. w sprawie szczegółowych warunków organizowania i prowadzenia szkoleń w stużbie cywilnej. URL:http://prawo.sejm. gov.pl/isap.nsf/download.xsp/WDU20150000960 /O/D20150960.pdf [in Polish].

Tomaszwska A., Szymański R. Szkolenia centralne w 2014 r. Przegląd Stużby Cywilnej. 2014. № 4(31). lipiec-sierpień. S. 14 [in Polish].

Ustawa z dnia 18 grudnia 1998 r. o stużbie cywilnej. URL: http://prawo.sejm.gov.pl/isap.nsf/ DocDetails.xsp?id=WDU19990490483 [in Polish].

Ustawa z dnia 21 listopada 2008 r. o stużbie cywilnej. URL: http://prawo.sejm.gov.pl/isap.nsf/ download.xsp/WDU20170001889/U/D20171889Lj.pdf [in Polish].

Ustawa z dnia 24 sierpnia 2006 r. o stużbie cywilnej. URL: http://prawo.sejm.gov.pl/isap.nsf/ DocDetails.xsp?id=WDU20061701218; (дата звернення 03.06.2020) [in Polish].

Ustawa z dnia 5 lipca 1996 r. o stużbie cywilnej. URL: http://prawo.sejm.gov.pl/isap.nsf/DocDetails.xsp?id=WDU19960890402 [in Polish].

Van der Hoven R. La formation europeenne destine aux hauts fonctionnaires des Etats mwmbers de I'Union europeenne Rutger van der Hoven Available from internet URL: http:// www.eipa.eu len/eipascode/downloadarticle/\&tid=1633 [in Polish].

Wytyczne dotyczace wdrażania Polityki szkoleniowej $w$ stużbie cywilnej. URL: https:// dsc.kprm.gov.pl/sites/default/files/pliki/zal._nr_3.pdf; [in Polish]. 